\title{
Breve fra Rusland. Sandheden om det russiske despoti ${ }^{1}$
}

\author{
Marquis de Custine \\ Oversatt fra fransk av Fritz Wolder \\ Hasselager: Helikon 2020 \\ 158 sider. ISBN 9788791817939
}

Omtalt av Søren Riishøj [lektor emeritus, Statskundskab, Syddansk Universitet (SDU), sr@sam.sdu.dk]

Marquis de Custine var en fransk aristokrat, som i 1843 udsendte et større værk, en samling breve fra en rejse i Rusland med titlen Rusland $i$ året 1839. Værket udkom på få år i seks oplag og i oversættelser i udlandet. Nu har vi i Danmark anno 2020 fået brevene i en oversættelse, som er et uddrag af Custines rejseoplevelser.

Som Fritz Wolder skriver i forordet, Rusland var i 1839 et fjernt og mystisk land. Ikke mange, om nogen, besøgte dengang Rusland, som Marquis de Custine gjorde. Rejsen blev påbegyndt i starten af 1839 og varede helt frem til september måned samme år. St. Petersborg oplevede han som en langt tristere og mere grå by end Moskva. Det første, der slog mig i Moskvas gader, var, skriver han, at befolkningen syntes livligere i sin færden og mere fri i sin munterhed end i St. Petersborg. Man indånder her en friskere luft end i den øvrige del af riget (s. 134). Det var den reaktionære tsar Nikolaj I, der havde magten det år, hvor Custine ankom. Custine fik flere gange adgang til Vinterpaladset, hoffet og tsaren selv, men det skabte ikke et mere positivt billede af tsaren og landet:

"Når jeg nærmer mig kejseren og ser hans skønhed, beundrer jeg dette underværk.... Når jeg på nært hold betragter denne personlighed, enestående i verden, tror jeg, at hans hoved har to ansigter ligesom Janus, og at ord som vold, forvisning, undertrykkelse, eller hvad der kan stå for dem alle, Sibirien, er indgraveret på den af de to pander, jeg ikke kan se«(s. 120).

Hans oplevelser tegner bestemt ikke noget positivt billede af Rusland, tværtimod. Hans direkte konfrontation med den russiske virkelighed var en chokerende oplevelse. Han opdagede, at befolkningen levede som slaver under den almægtige hersker.

\footnotetext{
${ }^{1}$ En tidligere versjon av denne bokomtalen har blitt publisert på nettstedet $M r$. East (https://mreast. $\mathrm{dk} /$ ). Denne versjonen publiseres med tillatelse fra Mr. East.
} 
Custine så i sit eget hjemland Frankrig adelen som modvægt til monarkers absolutte magt. At Rusland var, som det var, skyldtes ifølge Custine i høj grad, at den russiske adel havde svigtet så groft. Et undertrykt folk har altid fortjent sin straf, tyranniet er nationernes eget værk. Adelen tilbad tsaren og giorde sig dermed medskyldig i hans misbrug af den øverste magt, for at den selv kunde fortsætte med at undertrykke folket, mente han (s. 59-60). Rusland var en nation af stumme. En magiker havde forvandlet tres millioner mennesker til automater, der ventede på en anden heksemesters tryllestav for at blive genfødt og vækket til live (s. 98). Hvor friheden mangler, mangler sjælen og sandheden, hævder Custine (s. 89). Den ortodokse kirke har Custine heller ikke meget til overs for. Præsternes indflydelse begrænser sig til at få folket og de store herrer til at gøre korsets tegn og udføre knæbøjninger. Trods dyrkelsen af Helligånden har Rusland altid haft sin Gud på jorden - ligesom Batu og Tamerlan er den russiske tsar forgudet af sine undersåtter, skriver han.

Han berører også forholdet til Vesten. Siden Peter den Store har det problem, som de russiske herskere skulle løse, været at udnytte de europæiske nationers administrative fremskridt for bedre at kunne regere tres millioner mennesker på en orientalsk manér, skriver Custine (s. 88). Ruslands politiske regime ville ikke kunne overleve tyve års fri kommunikation med det vestlige Europa (s. 62). Rusland er placeret på grænsen mellem to kontinenter. Hvad der kommer fra Europa, er ikke af en sådan natur, at det kan sammensmeltes fuldstændigt med det, man har bragt med sig fra Asien. Dette russiske samfund havde hidtil kun udviklet sig ved at tåle volden og uoverensstemmelsen mellem to over for hinanden stillede og meget forskellige civilisationer (s. 86).

Man skal besøge dette land, fortsætter han (s. 92), for at lære at hade reservation: Russerne har intet af deres eget undtagen lydighed og efterligning. Deres åndelige orientering, deres dømmekraft, deres frie vilje tilhører herskeren (tsaren) (s. 149). Rusland udgjorde ifølge Custine en dødelig trussel mod det frie og civiliserede Europa. I befolkningen herskede der udbredt modstand mod fremmede. "Franskmændene og englænderne bilder sig ind, at de er alle andre folk overlegne". En rå skinsyge og barnlig misundelse dominerede hovedparten af russerne i deres forhold til mennesker fra andre lande, hævder Custine (s. 118).

De negative vurderinger skal ses i lyset af Frankrigs relationer dengang til Rusland. Efter den franske revolution og Napoleons omvæltning af den daværende europæiske orden havde sejrsmagterne på Wienerkongressen sikret genindsættelse af fyrster og bragt magtbalancen, en europæisk "koncert" og stabilitet, højt op på den politiske dagsorden. Den russiske tsar blev efter Wienerkongressen ligefrem kaldt "Europas gendarm». Denne politiske rolle gjorde ham ikke populær, slet ikke i Frankrig. Den store udbredelse af bogen skyldtes i høj grad den russiskfjendtlige indstilling, især i Frankrig.

I dag, som Wolder skriver, er bogen igen kommet til ære og værdighed. Den "kolde krig" er med Putin vendt tilbage, samtidig også de negative "fortællinger" om Rusland. Mange af Custines betragtninger genkendes anno 2020. Vurderingerne af 
Rusland (og Sovjetunionen) har været og er forbundet med graden af konfrontation mellem Rusland/Sovjetunionen og Vesten. Vesten har altid haft svært ved at and beslutte, om Rusland bør være en del af Europa. Rusland selv har haft samme problem, skal Rusland være europæisk eller snarere asiatisk, eller måske begge dele samtidigt? Under Jeltsin og Putin bevægede Rusland sig i perioder nærmere Europa, ja de talte ligefrem om russisk optagelse i NATO. Men det varede ikke ret længe. Sidst i 1990'erne, efter NATO-bombardementerne af Serbien, talte Jeltsin modsat om "kold fred". Putin følte, at hans støtte til USA efter 11. september ikke blev belønnet.

Hvorfor skal vi læse gamle rejseberetninger fra en fransk adelig fra 1800-tallet? Det er vigtigt at kende de historiske rødder til dagens "russofobi", og det bidrager Custines rejsebreve afgjort til. George Kennan, fadderen til »inddæmningspolitikken" over for Sovjetunionen under den gamle kolde krig, læste Custines værk med begejstring. I dag har identitetspolitik vundet terræn, Huntingtons tese om "clash of civilisations" lever stadig, og dagens "russofober" nikker sikkert genkendende til mange af Custines betragtninger fra dengang. Et konstruktivt middel til at formindske fobien er mere viden og respekt for andre kulturer. For nogle år siden blev der eksempelvis fra dansk side i Moskva afholdt kurser og møder om Grundtvig. Dialog og respekt for andre kulturer, som højskole-idéen står for, er et af flere midler til at mindske den fobi, der desværre har fået et mærkbart comeback, i høj grad også i vores egen del af verden. Derfor er Custines rejsebetragtninger interessante. Der er god grund til at udgive uddrag fra bogen på moderne dansk. 